\title{
Standard molar enthalpy of combustion and formation of quaternary ammonium tetrachlorozincate $\left[n-\mathrm{C}_{n} \mathrm{H}_{2 n+1} \mathrm{~N}\left(\mathrm{CH}_{3}\right)_{3}\right]_{2} \mathrm{ZnCl}_{4}$
}

\author{
Biyan Ren ${ }^{1}$, Shuying Zhang ${ }^{2}$, Bei Ruan ${ }^{1}, K^{\prime}$ ezhong $\mathrm{Wu}^{1 *}$ and Jianjun Zhang ${ }^{1}$
}

\begin{abstract}
The standard molar enthalpy of combustion $\left(\Delta_{C} H_{m}^{\circ}\right)$ and formation $\left(\Delta_{\mathrm{f}} H_{\mathrm{m}}^{\circ}\right)$ of quaternary ammonium tetrachlorozincate $\left[n-\mathrm{C}_{n} \mathrm{H}_{2 n+1} \mathrm{~N}\left(\mathrm{CH}_{3}\right)_{3}\right]_{2} \mathrm{ZnCl}$ have been determined for the hydrocarbon chain length from even number 8 to 18 of carbon atoms ( $n$ ) by an oxygen-bomb combustion calorimeter. The results indicated that the values of $\Delta_{\mathrm{c}} H_{\mathrm{m}}^{\circ}$ increased and $\Delta_{\mathrm{f}} H_{\mathrm{m}}^{\mathrm{O}}$ decreased with increasing chain length and showed a linear dependence on the number of carbon atoms, which were caused by that the order and rigidity of the hydrocarbon chain decreased with increasing the carbon atoms. The linear regression equations are $-\Delta_{c} H_{m}^{\circ}=1440.50 \mathrm{n}+3730.67$ and $-\Delta_{\mathrm{f}} H_{\mathrm{m}}^{\circ}=-85.32 \mathrm{n}+1688.22$.
\end{abstract}

Keywords: Combustion calorimeter, Energy of combustion, Enthalpy of combustion, Enthalpy of formation, Quaternary ammonium tetrachlorozincate

\section{Introduction}

The quaternary ammonium tetrachlorometallate with the general formula $\left[n-\mathrm{C}_{\mathrm{n}} \mathrm{H}_{2 \mathrm{n}+1} \mathrm{NR}_{3}\right]_{2} \mathrm{MX}_{4}(\mathrm{M}=\mathrm{Cu}, \mathrm{Mn}$, $\mathrm{Cd}, \mathrm{Zn}, \mathrm{Co}, \ldots, \mathrm{X}=\mathrm{Cl}, \mathrm{Br}, \mathrm{I}, \mathrm{R}$ is alkyl, or aryl) (short notation: $C_{n} C_{3} M$ ) have been attracted considerable attention because of their physical properties including ferro-, piezo- or pyroelectricity, ferri-, antiferro- or piezomagnetism and their technical application for electro- or magneto-optical devices (Blachnik et al. 1996; Kezhong et al. 2010). The advances in synthesis along with the ease of controlling various structural parameters (metal, halogen and number of carbon atoms in the alkylammonium ion) have made them ideal objects for studies by spectroscopy, calorimetry, diffraction, and a variety of other techniques (Abid et al. 2011; Donghua et al. 2011; Shymkiv et al. 2011). In addition, several theoretical studies have been undertaken to predict the behavior of the $C_{n} C_{3} M$ (Francesco et al. 2002; Gosniowska et al. 2000). However, the thermodynamic properties of the $C_{n} C_{3} M$ have been reported rarely in the literature. In the present work, the series of quaternary ammonium

\footnotetext{
* Correspondence: wukzh688@163.com

${ }^{1}$ Department of Chemistry and Material Science, Hebei Normal University, Shijiazhuang 050024, China

Full list of author information is available at the end of the article
}

tetrachlorozincate $\left[n-\mathrm{C}_{\mathrm{n}} \mathrm{H}_{2 \mathrm{n}+1} \quad \mathrm{~N}\left(\mathrm{CH}_{3}\right)_{3}\right]_{2} \mathrm{ZnCl}_{4} \quad(\mathrm{n}=8$, $10,12,14,16,18)$ are synthesized from ethanol solutions. The standard molar enthalpy of formation $\left(\Delta_{\mathrm{f}} H_{\mathrm{m}}^{\mathrm{o}}\right)$ and the standard molar enthalpy of combustion $\left(\Delta_{\mathrm{c}} H_{\mathrm{m}}^{\mathrm{o}}\right)$ of the $\mathrm{C}_{\mathrm{n}} \mathrm{C}_{3} \mathrm{Zn}$ have been determined by an oxygenbomb combustion calorimeter with increasing chain length at $T=298.15 \mathrm{~K}$.

\section{Experimental procedure}

$\mathrm{ZnCl}_{2}$, concentrated $\mathrm{HCl}$ and absolute ethanol were analytical grade. n-Octyltrimethylammonium chloride (A. P.), were purchased from TOKYO CHEMICAL INDUSTRY CO LTD (Japan). n-Decyltrimethylammonium chloride(A.P.), $n$-Dodecyltrimethylammonium chloride (A.P.), $n$-Tetradecyltrimethylammonium chloride(A. P.), n-Hexadecyltrimethylammonium chloride(A.P.), $n$-Trimethylstearylammonium chloride(A.P.) were purchased from J \& K CHEMICAL LTD. For the synthesis of $\mathrm{C}_{\mathrm{n}} \mathrm{C}_{3} \mathrm{Zn}$, the hot absolute ethanol solutions of $\mathrm{ZnCl}_{2}$, concentrated $\mathrm{HCl}$ and the corresponding quaternary ammonium were mixed in a 1:2:2 molar ratios. The solutions were concentrated by boiling for $1 \mathrm{~h}$, and then cooled to room temperature. After filtration, the products were recrystallized twice from absolute ethanol and then were placed in a vacuum desiccator for $10 \mathrm{~h}$ at about $353 \mathrm{~K}$. 
The $\mathrm{C}_{\mathrm{n}} \mathrm{C}_{3} \mathrm{Zn}$ were analyzed with an MT-3 CHN elemental analyzers (Japan) are listed in the following: Elemental analyses calc. (\%) for $\mathrm{C}_{8} \mathrm{C}_{3} \mathrm{Zn}$ : $\mathrm{C} 47.88, \mathrm{H} 9.43, \mathrm{~N} 5.08, \mathrm{Cl}$ 25.75; Found: C 47.45, H 9.50, N 5.13, Cl 24.99. Anal. Calcd for $\mathrm{C}_{10} \mathrm{C}_{3} \mathrm{Zn}$ : $\mathrm{C}$ 51.37, $\mathrm{H}$ 9.88, $\mathrm{N}$ 4.61, Cl 23.38; Found: C 50.98, H 9.95, N 4.58, Cl 22.81. Anal. calcd for $\mathrm{C}_{12} \mathrm{C}_{3} \mathrm{Zn}$ : C 54.26, $\mathrm{H}$ 10.25, N 4.22, $\mathrm{Cl} 21.41$; Found: $\mathrm{C}$ 53.93, $\mathrm{H}$ 10.34, N 4.26, $\mathrm{Cl}$ 21.25. Anal. Calcd for $\mathrm{C}_{14} \mathrm{C}_{3} \mathrm{Zn}$ : C 56.72, H 10.56, N 3.89, Cl 19.74; Found: C 56.06, H
10.20, N 3.84, $\mathrm{Cl}$ 19.03. Anal. Calcd for $\mathrm{C}_{16} \mathrm{C}_{3} \mathrm{Zn}$ : C 58.84, H 10.84, N 3.61, Cl 18.31; Found: C 58.91, H 10.77, N 3.62,Cl18.72. Anal. Calcd for $\mathrm{C}_{18} \mathrm{C}_{3} \mathrm{Zn}: \mathrm{C} 60.65, \mathrm{H}$ 11.07, $\mathrm{N}$ 3.37, Cl 17.08; Found: C 60.56, H 11.04, N 3.36, Cl 17.55 .

The combustion experiments were performed with a static bomb calorimeter (XRY-1A Shanghai). Benzoic acid (Thermochemical Standard, BCS-CRM-190r) was used as calibrant of the bomb calorimeter. Its massic

Table 1 The values of the combustion energies of the quaternary ammonium tetrachlorometallate $C_{n} C_{3} Z n$

\begin{tabular}{|c|c|c|c|c|c|c|c|c|}
\hline & No. & $m_{\mathrm{CnC} 3 \mathrm{Zn}} /$ & $\Delta T / \mathrm{K}$ & $\Delta \mathrm{m}_{\mathrm{ign}} / \mathrm{g}$ & $U_{\text {ign }} / J$ & $V_{\mathrm{NaOH}} / \mathrm{ml}$ & $U_{\mathrm{NaOH}} / \mathrm{J}$ & $-\Delta_{C} U_{m} / k J \cdot g^{-1}$ \\
\hline \multirow[t]{6}{*}{$\mathrm{C}_{8} \mathrm{C}_{3} \mathrm{Zn}$} & 1 & 0.4816 & 0.950 & 0.0033 & 10.71 & 3.88 & 23.20 & 27.478 \\
\hline & 2 & 0.5028 & 0.990 & 0.0031 & 10.06 & 3.78 & 22.60 & 27.432 \\
\hline & 3 & 0.4725 & 0.940 & 0.0041 & 13.30 & 4.08 & 24.40 & 27.703 \\
\hline & 4 & 0.3775 & 0.750 & 0.0028 & 9.09 & 4.00 & 23.92 & 27.658 \\
\hline & 5 & 0.5193 & 1.034 & 0.0025 & 8.11 & 4.40 & 26.31 & 27.741 \\
\hline & Ave. & & & & & & & $27.602 \pm 0.139$ \\
\hline \multirow[t]{6}{*}{$C_{10} C_{3} Z n$} & 1 & 0.5081 & 1.085 & 0.0041 & 13.30 & 2.85 & 17.04 & 29.762 \\
\hline & 2 & 0.5306 & 1.120 & 0.0039 & 12.66 & 2.89 & 17.28 & 29.422 \\
\hline & 3 & 0.5035 & 1.070 & 0.0038 & 12.33 & 3.39 & 20.33 & 29.631 \\
\hline & 4 & 0.4403 & 0.895 & 0.0030 & 9.74 & 2.30 & 13.75 & 29.804 \\
\hline & 5 & 0.4630 & 0.950 & 0.0030 & 9.74 & 2.90 & 17.34 & 29.640 \\
\hline & Ave. & & & & & & & $29.652 \pm 0.149$ \\
\hline \multirow[t]{6}{*}{$\mathrm{C}_{12} \mathrm{C}_{3} \mathrm{Zn}$} & 1 & 0.4907 & 1.115 & 0.0047 & 15.25 & 3.03 & 18.12 & 31.666 \\
\hline & 2 & 0.4591 & 1.040 & 0.0049 & 15.90 & 2.93 & 17.54 & 31.563 \\
\hline & 3 & 0.4706 & 1.060 & 0.0044 & 14.28 & 3.25 & 19.44 & 31.385 \\
\hline & 4 & 0.4566 & 1.040 & 0.0032 & 10.38 & 3.20 & 19.14 & 31.744 \\
\hline & 5 & 0.4673 & 1.055 & 0.0040 & 12.98 & 3.55 & 21.23 & 31.455 \\
\hline & Ave. & & & & & & & $31.563 \pm 0.147$ \\
\hline \multirow[t]{6}{*}{$\mathrm{C}_{14} \mathrm{C}_{3} \mathrm{Zn}$} & 1 & 0.4699 & 1.120 & 0.0025 & 8.11 & 2.45 & 14.65 & 33.238 \\
\hline & 2 & 0.5225 & 1.251 & 0.0037 & 12.01 & 3.65 & 21.83 & 33.372 \\
\hline & 3 & 0.4130 & 0.985 & 0.0039 & 12.66 & 2.46 & 14.71 & 33.241 \\
\hline & 4 & 0.5325 & 1.270 & 0.0047 & 15.25 & 2.45 & 14.65 & 33.251 \\
\hline & 5 & 0.4362 & 1.040 & 0.0042 & 13.63 & 3.75 & 22.43 & 33.214 \\
\hline & Ave. & & & & & & & $33.263 \pm 0.062$ \\
\hline \multirow[t]{6}{*}{$\mathrm{C}_{16} \mathrm{C}_{3} \mathrm{Zn}$} & 1 & 0.5125 & 1.270 & 0.0046 & 14.93 & 2.50 & 14.97 & 34.549 \\
\hline & 2 & 0.4720 & 1.160 & 0.0042 & 13.63 & 2.44 & 14.57 & 34.262 \\
\hline & 3 & 0.4902 & 1.210 & 0.0027 & 8.76 & 3.04 & 18.18 & 34.417 \\
\hline & 4 & 0.4758 & 1.170 & 0.0043 & 13.95 & 3.01 & 17.99 & 34.274 \\
\hline & 5 & 0.4577 & 1.130 & 0.0044 & 14.28 & 3.94 & 23.56 & 34.396 \\
\hline & Ave. & & & & & & & $34.379 \pm 0.118$ \\
\hline \multirow[t]{6}{*}{$\mathrm{C}_{18} \mathrm{C}_{3} \mathrm{Zn}$} & 1 & 0.5605 & 1.430 & 0.0030 & 9.74 & 3.04 & 18.18 & 35.580 \\
\hline & 2 & 0.5755 & 1.475 & 0.0058 & 18.82 & 3.03 & 18.12 & 35.729 \\
\hline & 3 & 0.5283 & 1.348 & 0.0062 & 20.12 & 3.42 & 20.45 & 35.557 \\
\hline & 4 & 0.4465 & 1.140 & 0.0034 & 11.03 & 3.65 & 21.83 & 35.583 \\
\hline & 5 & 0.4459 & 1.130 & 0.0038 & 12.33 & 3.65 & 21.83 & 35.315 \\
\hline & Ave. & & & & & & & $35.552 \pm 0.149$ \\
\hline
\end{tabular}


Table 2 The value of thermochemical functions of the quaternary ammonium tetrachlorometallate $C_{n} C_{3} Z n$

\begin{tabular}{|c|c|c|c|c|c|c|}
\hline & $C_{8} C_{3} Z n$ & $C_{10} C_{3} Z n$ & $C_{12} C_{3} Z n$ & $C_{14} C_{3} Z n$ & $C_{16} C_{3} Z n$ & $\mathrm{C}_{18} \mathrm{C}_{3} \mathrm{Zn}$ \\
\hline$-\Delta_{c} U_{\mathrm{m}}^{\circ} / \mathrm{kJ} \cdot \mathrm{mol}^{-1}$ & 15268 & 18010 & 20938 & 23929 & 26657 & 29557 \\
\hline$-\Delta_{\mathrm{c}} H_{\mathrm{m}}^{\mathrm{o}} / \mathrm{kJ} \cdot \mathrm{mol}^{-1}$ & 15297 & 18044 & 21009 & 24006 & 26740 & 29647 \\
\hline$-\Delta_{\mathrm{f}} H_{\mathrm{m}}^{\circ} / \mathrm{kJ} \cdot \mathrm{mol}^{-1}$ & 991.66 & 908.02 & 660.38 & 380.47 & 364.10 & 174.46 \\
\hline
\end{tabular}

energy of combustion is $\Delta_{c} U=-(26460 \pm 3.8) \mathrm{J} \cdot \mathrm{g}^{-1}$ under certificate conditions. The massic energy of combustion $\Delta_{\mathrm{c}} U_{\mathrm{m}}$ for each $\mathrm{C}_{\mathrm{n}} \mathrm{C}_{3} \mathrm{Zn}$ was fitted with equation $\Delta_{\mathrm{c}} U_{\mathrm{m}}=\left[-\varepsilon_{\text {(calor) }} \cdot \Delta T+\Delta m_{i g n} \cdot u_{i g n}+V_{\mathrm{NaOH}}(-59.7)\right] / m_{\mathrm{CnC} 3 \mathrm{Zn}}$, where $\varepsilon_{\text {cal }}$ is the energy equivalent of the calorimeter, $\Delta T$ is the calorimeter temperature change corrected, $\Delta m_{i g n}$ is the mass of the Nickel-chromium alloy for ignition and the massic energy is $u_{i g n}=-3.245 \mathrm{~kJ} \cdot \mathrm{g}^{-1}\left(U_{\text {ign }}=\Delta m_{i g n} \bullet u_{i g n}\right)$. $m_{\mathrm{CnC} 3 \mathrm{Zn}}$ is the mass of the $\mathrm{C}_{n} \mathrm{C}_{3} \mathrm{Zn}$ which were burned, $V_{\mathrm{NaOH}}$ is the volume of sodium hydroxid which consumed by nitric acid, the corrections for nitric acid formation were based on $-59.7 \mathrm{~kJ} \cdot \mathrm{mol}^{-1}$ for the molar energy of formation of $0.1 \mathrm{~mol} \cdot \mathrm{dm}^{-3} \mathrm{HNO}_{3}(\mathrm{aq})$ from $\mathrm{N}_{2}, \mathrm{O}_{2}$, and $\mathrm{H}_{2} \mathrm{O}(\mathrm{l})$ (Matos et al. 2002). The calibration results were corrected to the average mass of water added to the calorimeter: $2500.0 \mathrm{~g}$ and the volume of oxygen bomb was $300 \mathrm{ml}$. From five independent calibration experiments between $T$ $=295.15 \mathrm{~K}$ and $T=299.15 \mathrm{~K}$, the energy equivalent $\varepsilon_{\mathrm{cal}}=$ $(13965.4 \pm 4.7) \mathrm{J} \cdot \mathrm{K}^{-1}$ was obtained, where the uncertainty quoted is the standard deviation of the mean. For all experiments, ignition was made at $T=(298.150 \pm 0.001) \mathrm{K}$. Combustion experiments were performed in oxygen at a pressure $p=3.00 \mathrm{MPa}$ and in the presence of $10.00 \mathrm{~cm}^{3}$ of water added to the bomb (Matos et al. 2002).

\section{Results and discussion}

The individual results of all combustion experiments, together with the mean values and their standard

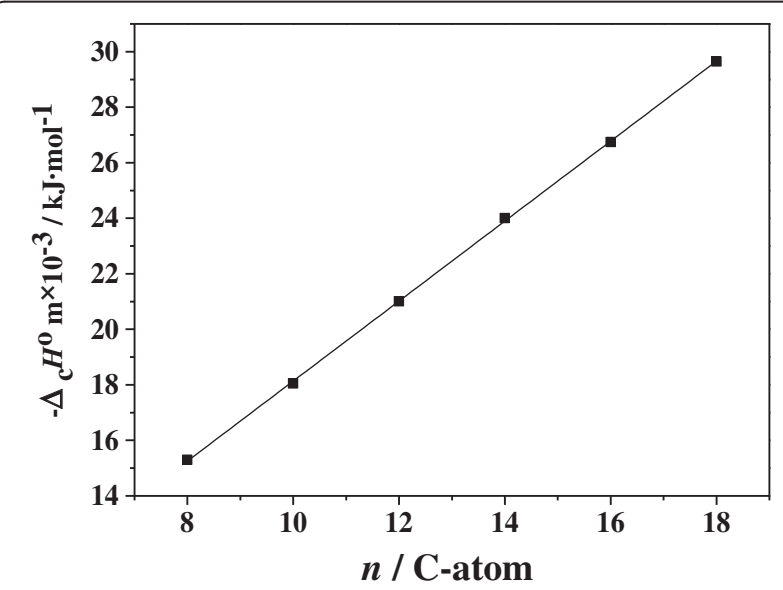

Figure 1 Plot of $\Delta_{c} H_{m}^{o}$ vs. number( $\left.n\right)$ of carbon-atoms in the quaternary ammonium tetrachlorometallate $C_{n} C_{3} Z n$. deviations, are given for each compound in Table 1. In accordance with normal thermochemical practice, the uncertainties assigned to the standard molar enthalpies of combustion are, in each case, equal to twice the overall standard deviation of the mean and include the uncertainties in calibration (Henoc et al. 2009). The results are referred to the following reactions $(1 \sim 6)$ and the following equation $(7 \sim 9)$ :

$$
\begin{aligned}
& {\left[\mathrm{C}_{8} \mathrm{H}_{17} \mathrm{~N}\left(\mathrm{CH}_{3}\right)_{3}\right]_{2} \mathrm{ZnCl}_{4}(\mathrm{~s})+\frac{69}{2} \mathrm{O}_{2}(g)} \\
& =\mathrm{ZnO}(s)+22 \mathrm{CO}_{2}(g)+4 \mathrm{HCl}(l)+24 \mathrm{H}_{2} \mathrm{O}(l) \\
& \quad+\mathrm{N}_{2}(g)
\end{aligned}
$$

$$
\begin{aligned}
& {\left[\mathrm{C}_{10} \mathrm{H}_{21} \mathrm{~N}\left(\mathrm{CH}_{3}\right)_{3}\right]_{2} \mathrm{ZnCl}_{4}(\mathrm{~s})+\frac{81}{2} \mathrm{O}_{2}(g)} \\
& =\mathrm{ZnO}(\mathrm{s})+26 \mathrm{CO}_{2}(g)+4 \mathrm{HCl}(\mathrm{l})+28 \mathrm{H}_{2} \mathrm{O}(l) \\
& \quad+\mathrm{N}_{2}(\mathrm{~g})
\end{aligned}
$$

$$
\begin{aligned}
& {\left[\mathrm{C}_{12} \mathrm{H}_{25} \mathrm{~N}\left(\mathrm{CH}_{3}\right)_{3}\right]_{2} \mathrm{ZnCl}_{4}(\mathrm{~s})+\frac{93}{2} \mathrm{O}_{2}(g)} \\
& =\mathrm{ZnO}(s)+30 \mathrm{CO}_{2}(g)+4 \mathrm{HCl}(\mathrm{l})+32 \mathrm{H}_{2} \mathrm{O}(l) \\
& \quad+\mathrm{N}_{2}(\mathrm{~g})
\end{aligned}
$$

$$
\begin{aligned}
& {\left[\mathrm{C}_{14} \mathrm{H}_{29} \mathrm{~N}\left(\mathrm{CH}_{3}\right)_{3}\right]_{2} \mathrm{ZnCl}_{4}(\mathrm{~s})+\frac{105}{2} \mathrm{O}_{2}(g)} \\
& =\mathrm{ZnO}(\mathrm{s})+34 \mathrm{CO}_{2}(g)+4 \mathrm{HCl}(l)+36 \mathrm{H}_{2} \mathrm{O}(l) \\
& \quad+\mathrm{N}_{2}(\mathrm{~g})
\end{aligned}
$$

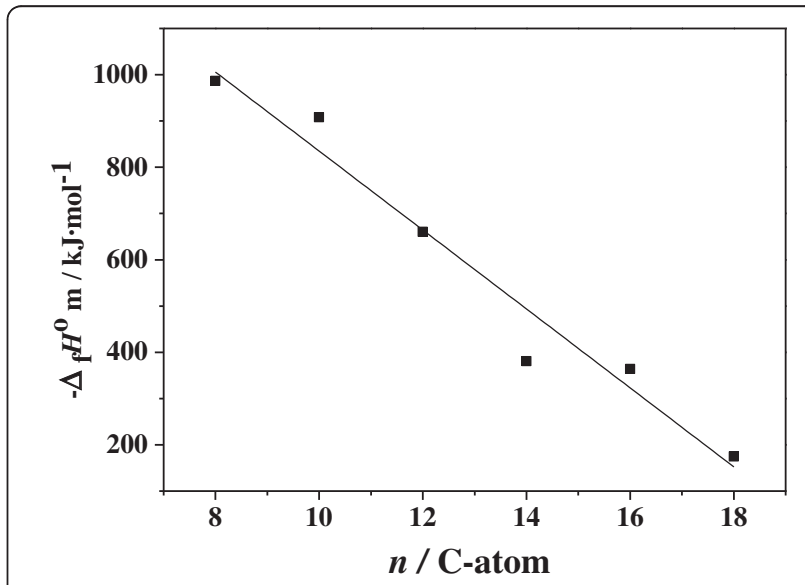

Figure 2 Plot of $\Delta_{\mathrm{f}} H_{\mathrm{m}}^{\circ}$ vs. number $(n)$ of carbon-atoms in the quaternary ammonium tetrachlorometallate $\mathrm{C}_{n} \mathrm{C}_{3} \mathrm{Zn}$. 


$$
\begin{aligned}
& {\left[\mathrm{C}_{16} \mathrm{H}_{33} \mathrm{~N}\left(\mathrm{CH}_{3}\right)_{3}\right]_{2} \mathrm{ZnCl}_{4}(s)+\frac{117}{2} \mathrm{O}_{2}(g)} \\
& =\quad \mathrm{ZnO}(s)+38 \mathrm{CO}_{2}(g)+4 \mathrm{HCl}(\mathrm{l})+40 \mathrm{H}_{2} \mathrm{O}(\mathrm{l}) \\
& \quad+\mathrm{N}_{2}(g) \\
& {\left[\mathrm{C}_{18} \mathrm{H}_{37} \mathrm{~N}\left(\mathrm{CH}_{3}\right)_{3}\right]_{2} \mathrm{ZnCl}_{4}(s)+\frac{129}{2} \mathrm{O}_{2}(g)} \\
& =\quad \mathrm{ZnO}(s)+42 \mathrm{CO}_{2}(g)+4 \mathrm{HCl}(\mathrm{l})+44 \mathrm{H}_{2} \mathrm{O}(l) \\
& \quad+\mathrm{N}_{2}(g) \\
& \Delta_{c}{H^{o}}^{o}=\mathrm{M} \Delta_{c} U^{o}{ }_{m}+\Delta n R T \\
& \Delta n=n_{g}(\text { product })-n_{g}(\text { reactant }) \\
& \Delta_{f} H^{o}{ }_{m}\left(C_{\mathrm{n}} C_{3} \mathrm{Zn}\right)=\Sigma \mathrm{V}_{B} \Delta_{f} H_{m}{ }^{o}(B)-\Delta_{c} H^{o}{ }_{m}
\end{aligned}
$$

Where $R$ is the molar gas constant and $\mathrm{M}$ is the molar mass of the $C_{n} C_{3} Z n$. The $V_{B}$ is the stoichiometric coefficient and the $\Delta_{\mathrm{f}} H_{\mathrm{m}}^{\mathrm{o}}(\mathrm{B})$ is the standard molar enthalpy of formation of the combustion products. The standard molar enthalpies of formation of $\mathrm{ZnO}(\mathrm{s}), \mathrm{H}_{2} \mathrm{O}$ (l) and $\mathrm{CO}_{2}(\mathrm{~g})$ at $T=298.15 \mathrm{~K},-(348.28) \mathrm{kJ} \cdot \mathrm{mol}^{-1},-(285.830$ $\pm 0.042) \quad \mathrm{kJ} \cdot \mathrm{mol}^{-1}$ and $-(393.51 \pm 0.13) \quad \mathrm{kJ} \cdot \mathrm{mol}^{-1}$ (Manuel et al. 2010). The $\Delta_{\mathrm{f}} H_{\mathrm{m}}^{\mathrm{o}}$ of the $\mathrm{C}_{\mathrm{n}} \mathrm{C}_{3} \mathrm{Zn}$ resulted from the $\Delta_{\mathrm{c}} H_{\mathrm{m}}^{\mathrm{o}}$ by an oxygen-bomb combustion calorimeter at $T=298.15 \mathrm{~K}$. Table 2 lists the values of the standard molar energies $\Delta_{\mathrm{c}} U_{\mathrm{m}}^{\mathrm{o}}$, the enthalpies of combustion $\Delta_{\mathrm{c}} H_{\mathrm{m}}^{\mathrm{o}}$ and the standard molar enthalpies of formation $\Delta_{\mathrm{f}} H_{\mathrm{m}}^{\mathrm{o}}$ result form $\Delta_{\mathrm{c}} U_{\mathrm{m}}^{\mathrm{o}}$ for the $\mathrm{C}_{\mathrm{n}} \mathrm{C}_{3} \mathrm{Zn}$.

The influence of the hydrocarbon chain length on $\Delta_{\mathrm{c}} H_{\mathrm{m}}^{\mathrm{o}}$ and $\Delta_{\mathrm{f}} H_{\mathrm{m}}^{\mathrm{o}}$ of the $\mathrm{C}_{\mathrm{n}} \mathrm{C}_{3} \mathrm{Zn}$ has been obtained for chain lengths from 8 to 18 carbon atoms. The values of $\Delta_{\mathrm{c}} H_{\mathrm{m}}^{\mathrm{o}}$ and $\Delta_{\mathrm{f}} H_{\mathrm{m}}^{\mathrm{o}}$ show a linear dependence on the number of carbon atoms from experimental data analysis. Figure 1, Figure 2 show a plot of the calculated $-\Delta_{\mathrm{c}} H_{\mathrm{m}}^{\mathrm{o}}$ and $-\Delta_{\mathrm{f}} H_{\mathrm{m}}^{\mathrm{o}}$ vs. C-atoms (n) that gave a straight line relationship from the values of Table 2. The linear regression equation are $-\Delta_{\mathrm{c}} H_{\mathrm{m}}^{\mathrm{o}}=1440.50 \mathrm{n}+3730.67$ with a correlation coefficient $r=0.9998$ and $-\Delta_{\mathrm{f}} H_{\mathrm{m}}^{\mathrm{o}}=-85.32 \mathrm{n}+$ 1688.22 with $r=0.9512$. A striking feature is that $\Delta_{\mathrm{c}} H_{\mathrm{m}}^{\mathrm{o}}$ increased and $\Delta_{\mathrm{f}} H_{\mathrm{m}}^{\mathrm{o}}$ decreased with increasing the chain length. This reason is that the structures of $\mathrm{C}_{n} \mathrm{C}_{3} \mathrm{Zn}$ are characteristic of the piling of sandwiches in which a twodimensional cavities of $\mathrm{ZnCl}_{4}^{2-}$ tetrahedra is sandwiched between two alkylammonium layers. The layers are bound by van der Waals forces between $\left(\mathrm{CH}_{2}\right)_{\mathrm{n}} \mathrm{CH}_{3}$ groups and by long-range Coulomb forces. The $-\mathrm{N}(\mathrm{CH})_{3}^{3+}$ groups of the chains occupy the cavities of the $\mathrm{ZnCl}_{4}^{2-}$ layers and are bonded by ion bonds to the chlorine atoms (Weizhen et al. 2011). As the hydrocarbon chain length increases, the formation of the chain conformer plays a more important role in the structural phase transitions. It is known that the order and rigidity of the hydrocarbon chain were decreased with increasing the carbon atoms, that is with increasing mean number of conformationally flexible chain in $\mathrm{C}_{\mathrm{n}} \mathrm{C}_{3} \mathrm{Zn}$ (Nobuaki et al. 2011), furthermore, the intensities of the ion bonds and van der Walls force decrease with increasing the carbon atoms resulting in that the values of $\Delta_{\mathrm{c}} H_{\mathrm{m}}^{\mathrm{o}}$ and $\Delta_{\mathrm{f}} H_{\mathrm{m}}^{\mathrm{o}}$ show a linear dependence on the carbon atoms.

\section{Conclusions}

The standard molar enthalpy of combustion and formation of quaternary ammonium tetrachlorozincate [n$\left.\mathrm{C}_{\mathrm{n}} \mathrm{H}_{2 \mathrm{n}+1} \mathrm{~N}\left(\mathrm{CH}_{3}\right)_{3}\right]_{2} \mathrm{ZnCl}_{4}(\mathrm{n}=8,10,12,14,16,18)$ have been measured by an oxygen-bomb combustion calorimeter. The results indicated that the values of the standard molar combustion enthalpies $\Delta_{\mathrm{c}} H_{\mathrm{m}}^{\mathrm{o}}$ of these compounds increased with increasing chain length and the standard molar formation enthalpies $\Delta_{\mathrm{f}} H_{\mathrm{m}}^{\mathrm{o}}$ of these compounds decreased with increasing chain length and showed a linear dependence on the number of carbon atoms.

\section{Competing interests}

The authors declare they have no competing interests in relation to this article.

\section{Authors' contributions}

KZW participated in the design of the experiment; All authors equally participated in the preparation of the manuscript, read and approved the final manuscript.

\section{Acknowledgements}

This project was financially supported by National Natural Science Foundation of China (No.21073052, 21246006), Natural Science Foundation of Hebei Province (No. B2012205034), and Science Foundation of Hebei Normal University (L2011K04).

\section{Author details}

'Department of Chemistry and Material Science, Hebei Normal University, Shijiazhuang 050024, China. ²Department of Basic Course, the Chinese People's Armed Police Force Academy, Langfang 065000, China.

Received: 28 December 2012 Accepted: 28 February 2013 Published: 9 March 2013

\section{References}

Abid H, Samet A, Dammak T (2011) Electronic structure calculations and optical properties of a new organic-inorganic luminescent perovskite: $\left(\mathrm{C}_{9} \mathrm{H}_{19} \mathrm{NH}_{3}\right)$ ${ }_{2} \mathrm{Pbl}_{2} \mathrm{Br}_{2}$. J Lumin 131:1753-1757

Blachnik R, Siethoff C (1996) Thermoanalytical and X-ray study of some alkylammonium tetrachlorozincates. Thermochim Acta 278:39-47

Donghua H, Youying D, Zhcheng T (2011) Crystal structures and thermochemistry on phase change materials $\left(n-\mathrm{C}_{n} \mathrm{H}_{2 n+1} \mathrm{NH}_{3}\right)_{2} \mathrm{CuCl}_{4}(\mathrm{~s})$ ( $n=14$ and 15). Sol Energy Mater Sol Cells 95:2897-2906

Neve F, Francescangeli O, Crispini A (2002) Crystal architecture and mesophase structure of long-chain N-alkylpyridinium tetrachlorometallates. Inorg Chim Acta 338:51-58

Gosniowska M, Ciunik Z, Bator G, Jakubas R, Baran J (2000) Structure and phase trransitions in tetramethylammonium tetrabromoindate(III) and tetraethylammonium tetrabromoindate(III) crystals. J Mol Struct 555:243-255 Flores H, Adriana Camarillo E, Mentado J (2009) Enthalpies of combustion and formation of 2-acetylpyrrole, 2-acetylfuran and 2-acetylthiophene. Thermochim Acta 493:76-79

Kezhong W, Jianjun Z (2010) Subsolidus binary phase diagram of $\left(n-\mathrm{C}_{n} \mathrm{H}_{2 n+1} \mathrm{NH}_{3}\right)$ ${ }_{2} \mathrm{ZnCl}_{4}(\mathrm{n}=14,16,18)$. J Therm Anal Calorim 101:913-917

Matos MAR, Monte MJS, Hillesheim DM (2002) Standard molar enthalpies of combustion of the three trans-methoxycinnamic acids. J Chem Thermodyn 34:499-509 
Manuel AV, da Silva R, Ana IMC, Lobo F (2010) Enthalpies of combustion, vapour pressures, and enthalpies of sublimation of the 1,5- and 1,8diaminonaphthalenes. J Chem Thermodyn 42:371-379

Shymkiv RM, Sveleba SA, Karpa IV, Katerynchuk IN, Kunyo IM, Phitsych El (2011) Electronic spectra and phase transitions in thin $\left[\mathrm{N}\left(\mathrm{CH}_{3}\right)_{4}\right]_{2} \mathrm{CuCl}_{4}$ microcrystals. J Appl Spectroscopy 78:823-828

Kitazawa N, Aono M, Watanabe Y (2011) Synthesis and luminescence properties of lead-halide based organic-inorganic layered perovskite compounds $\left(\mathrm{C}_{n} \mathrm{H}_{2 n+1} \mathrm{NH}_{3}\right)_{2} \mathrm{Pbl}_{4}(\mathrm{n}=4,5,7,8$ and 9). J Phys Chem Solids 72:1467-1471 Weizhen C, Kezhong W, Xiaodi L, Liuqin W, Biyan R (2011) Subsolidus binary phase diagram of the perovskite type layer materials $\left(n-\mathrm{C}_{n} \mathrm{H}_{2 n+1} \mathrm{NH}_{3}\right)_{2} \mathrm{ZnCl}_{4}$ $(\mathrm{n}=10,12,14)$. Thermochim Acta 521:80-83

doi:10.1186/2193-1801-2-98

Cite this article as: Ren et al.: Standard molar enthalpy of combustion and formation of quaternary ammonium tetrachlorozincate $\left[n-C_{n} H_{2 n+1}\right.$ $\left.\mathrm{N}\left(\mathrm{CH}_{3}\right)_{3}\right]_{2} \mathrm{ZnCl}_{4}$. SpringerPlus 2013 2:98.

\section{Submit your manuscript to a SpringerOpen ${ }^{\circ}$} journal and benefit from:

- Convenient online submission

- Rigorous peer review

- Immediate publication on acceptance

- Open access: articles freely available online

- High visibility within the field

- Retaining the copyright to your article 